\title{
A Brief Appraisal of The TURKISH ECONOMIC DEVELOPMENT
}

\author{
Necdel SERIIY \\ Professor of International \\ Economics, \\ Faculty of Political Sciences \\ Ankara University
}

During the recent period between the Second World We.r and today, the basic outlines of Turkey's place in the world may be summarized from the economic standpoint in the follwing terms.

The most significant event that has attracted attention in the international scene after the Second World War has been the strennuous efforts deployed by numerous countries with widely different economic, social, and pnitical systems, to complete their economic recovery and continue their economic development.

During the post war era the most serious problem facing Turkey was to be able to accelerate the efforts to strengthen its economy after the standstill of the period 1938-1945, in order to meet various requirements of the nation.

As it will be recalled, although Turkey had remained outside the war, it was forced to undertake defense expenditures which far exceeded its economic potential. Subjected to the unfavorable effects of the war in most onorous way, Turkey had been forced to save its foreign exchange resources which could not be spent during the period 19381945 embarked in 1948 a policy aimed at developing its economy and its efforts gained momentum as from 1950.

This paper was prepared in December 1982 
This policy directed towards increasing the standard of living and economic potential of the nation was linked at the same time to the development of economic relations with foreign countries and to a concurrent rearrangement in foreign policy.

In the beginning of 1950's when countries having an average income under 500 dollars were classified as under. developed, Turkey had a population of 21 million, population rate of increase 3 percent per annum and the average per capita income under 200 dollars.

The place of the industrial sector in economic activities was significant and Turkey's share in world trade was. 48 percent. Furthermore, the agricultural sector which provided 49.4 percent of the G.M.P. employed 69.4 percent of the working population and 97.2 percent of exports were composed of agricultural products.

Turkey which had all the characteristics of underdeveloped economies had found a comparatively suitable atmosphere during 1949-1950 to embark on its development effort both due to the availability of economic means and existence of appropriate political atmosphere.

The establishment of the democratic system of government based on multi-party free democratic order and Turkey's participation in the Korean War for the preservation of the international peace had earned great respect for Turkey in the world public opinion.

The implementation of an extremely liberal economic policy brought about a completely new dynamism in Turkey, our economy began to develop rapidly, activities began to diversify and alongside the public sector a private sector and a class of enterprising businessmen and industrialists began to appear.

The economic development process acquired a substantial speed due to the existence of a relatively adequate gold and foreign exchange reserves substantial amounts of foreign aid and favorable climatic conditions. However, the inflationist policies in increased doses and the econo- 
mic policy contradicting the realities of Turkey led the country as from 1954 into economic and political imbalances.

After 1960 we observe that the mixed nature of the economic system and planned economic development were turned into a constitutional institutions. The purpose of this new preference was to be able to utilize the existing resources more efficiently and to direct the economy towards more rational objectives.

At the end of the third 5-Year plan Turkey with a population of 42 million has an average per capita income of around 1.000 dollars. The share of industry in the G.M.P. has increased to 22.9 percent and the share of agriculture has fallen to 23.8 percent. Yet 57.7 percent of the working population is still employed in the agricultural sector and 80-85 percent of exports are agricultural products.

Although the rapid population increase and the continued significant increases in the per capita income have not yet reached desired levels the improvements in the income distribution create a lively domestic demand for goods and services.

In the course of 1970's significant developments far different than those of previous years have occurred in the world economy.

The 1970's have been characterized by such important problems as the soaring inflation in the economics of both developing and developed countries, increases in unemployment, frequent fluctuations in exchange rates, energy crisis and lack of international liquidity.

Alongside these certain new elements which have changed the balance among conventional economic powers have begun to influence world economy and political life.

In other words alongside U.S.A. and USSR, EEC, China, Japan and OPEC countries have demonstrated that they also could seriously influence world economy.

Consequently, the bi-polar dynamic equilibrium in the world cconomy has assumed a multi-polar appearance. 
In the industrialized countries faced with an inadequacy of investments the governments concerned have given preference to increased public expenditure in order to maintain the employmant levels.

Hcwever, while the total demand level has been increased by expansionist monatery and financial policies the production levels have not been increased at the same rate and the unexpected major increase in crude oil prices also increased the costs rapidly and created a condition where inflation and unemployment prevailed together.

The influence of economic crisis on the developing countries has been lower rates of development and increases in price levels.

The average rate of increase in the developing countries has been 5.5 percent in 1972 and 3.5 percent in 1975.

With its average rate of increase of 6.9 percent between 1963-1972, 5.4 percent in 1973, 7.4 percent in 1974, 8 percent in 1975 and 7.2 percent in 1976 Turkey has been the only country in the Western World, outside some major oil producing countries to achieve such a high rate of increase.

This does not mean however that Turkey has substantially resolved its development problems.

In addition to the recent trends in the world trade prices and capital movements and especially the unemployment in West European countries having various unfavorable effects on economics in Turkey a number of international problems which have special importance for Turkey have been influencing our international relations.

These problems are Turkish-U.S. relations, Cyprus and relations between Turkey and EEC.

The major economic problems of Turkey which also carry the characteristics of the recent trends in the world eccnomy are continuously increasing deficits in balance cf payments, inflation, lack of savings and unemployment. Especially in the year of 1977 in respect to problems of fcreign payments Turkey has arrived at a very difficult 
and dangerous point in arranging its international economic relations.

Due to (these) unfavorable conditions the rate of GNP raised only to 3.9 per cent in 1977, 2.9 in, 1978, 0.4 in 1979 and 1.1 in 1980.

For the purpose of reestablishing a rapid growth proces in Turkish economy, a set of stabilization measures were put into force on January 24, 1980 which aimed primarily at to decrease and to control the rate of inflation by a lower demand, to increase the domestic savings as well as export and to stabilize the economy at a high level of price.

In late 1980's, the so-called January 24 decisions which were set up as a group of acceptable and realizable measures began to give increasingly fruitful results. This is largely attributable to the peaceful period free of idiological strikes and anarchy after September 12, 1930 as well as to the great support of Turkish people. As a result Turkish economy regained stabilization, economic relations with foreign countries were increasingly established and a more rapid development rate was realized resulting in an inflation rate decreased to below $30 \%$ from about $100 \%$.

The January 24 measures which were decisively applied contributed to the raising of development rate to 4.3 in 1981 and 4.4. in 1982 which is expected to reach to 4.8 in 1983.

As before mentioned, one of the basic aims of the stabilization measures was to take inflation under control which was realized by decreasing the rate of inflation measurable with wholesale price indexes to $36.8 \%$ at the end of 1981 and to $24.8 \%$ in 1982 while it was $94.7 \%$ in 1980 . Officially estimated ratefor 1983 is $20 \%$. It will, however, be a more realistic estimation that the inflation rate be about $22-23$ $\%$ in 1983 bearing in mind some bottlenecks in exportation.

On the other hand, export values raised from 2.261 billion dolars in 1979 to 2.910 billion dolars in 1980 and by a $62 \%$ increase to 4.703 billion dolars in 1981 and by a $22 \%$ increase to 5.746 billion dolars in 1982 . It is estimated that this value would reach to 6.6 billion dolars in 1983 which iplies an increase of $15 \%$. 
Import values increased 13 and $11 \%$ respectively in 1981 and 1982 which are expected to 9.5 billion dolars in 1983 by an increase of $8 \%$. Such affirmative results realized in Turkey's foreign trade contribute a great deal to decreasing the current balance deficit.

The increasing level of foreign exchange sent to Turkey by Turkish workers in foreign countries is another important factor which conduces to decrease the current balance deficit. The total worker remittance was 8.878 billion dolars in the period of 1961-1978 which raised to 1.694 billion dolars in 1979, to 2.071 in $1980,2.490$ in 1981 and 2.350 in 1982. The small amount of decrease in 1982 is largely attributable to fluctuations in European currencies.

As a result of increased relations with foreign countries, new engineering and contracting firms capable of undertaking services in foreign countries and competing with great foreign firms were established. The number of Turkish firms reached to 242 at the end of 1982 which was only 22 in 1978. In the terms of money, such contracts summed up 12.576 billion dolars in 1982 while it was 1.629 billion dolars in 1978. The amount of foreign exchange transferred to Turkey by contractors increased to 209.3 million dolars in 1982 from 56.3 million dolars in 1978.

In spite of the success gained in decreasing the inflation rate and increasing the production and export, the financial sector could not have been successful to maintain the proper result reached at the beginning. Bankcrupcy of bankers had also been destructive for the banking sector which had to be supported by the Central Bank. Thus the improper effects of this bankcrupcy could have been prevented by the measures taken in time. This situation, however, necessitates to reorganize the financial sector.

Unemployment is still a serious problem that should be paid due consideration although a remarkable increase was realized both in production and export after the Jan. 24 decisions. It should not be forgotten that the decreased employment possibilities and increased rate of uneployment are unavoidable results of untiinflatory policy. 
The excess manpower which defines the negative difference between the civilian employment supply and civilian employment demand reached to 3.284 .500 in 1982 while it was 2.366 .600 in 1979. The number of openly unemployed persons which is included in the above mentioned figures was 702.600 in 1979 and reached to 1.103 .300 in 1982 .

For today, the most important mechanism that prevents the open unemployment to be a very serious economic, social and political source of conflict for Turkey is the structure of family in our country. But it should not be expected that this mechanism would play the same role of buffer for a greater open unemployment rate.

Therefore, utmost importance should be given -today and in the future- to follow a development policy that would enable to create increasingly new employment possibilities under controlled inflatory conditions. Efforts also should be made to increase our export, to encourage foreign investments in Turkey which will ensure the introduction of recent and advanced techniques and to accelerate the transfer of license, patent, know-how and technology. 